\title{
Tutoring and Mentoring at the University Level: Experiences in Padua and Burgos
}

\author{
${ }^{1}$ Da Re Lorenza, ${ }^{2}$ Raquel Casado-Muñoz, ${ }^{2}$ Montserrat Collado-Fernández \\ ${ }^{1}$ University of Padua, ${ }^{2}$ University of Burgos
}

\begin{abstract}
Over recent years and in view of the Bologna Declaration, tutoring and mentoring have become ever more commonplace in the University context. Although tutoring is an age-old practice, it has only recently been introduced in different areas of human activity (educational, academic, business and professional). During the last decade, the Italian university has officially introduced tutoring - both normal and peer-implemented - services intending to assist students, to provide information, and to analyze the activities carried out during the precedent year's activities. The tutor is entrusted with the task of accompanying students who have decided to embark on an academic career, and in particular when they encounter difficulties. The Spanish University has proposed an "accessible system of support and guidance for enrolled students". That contribution will be described here and then compared with two models of peer tutoring and mentoring implemented by the University of Padua and the Universidad de Burgos in order to reflect upon their features, dimensions and potential.
\end{abstract}

\section{Introduction}

Many European universities became interested in the '80's in creating placement services and programs not limited to merely providing information but also actively engaged in helping to integrate and to educate young people in view of empowering individual and social perspectives (Isfol, 2005) [1]

In 1998 Watts e Esbroeck proposed working models of university services at a European level diversified on the basis of two criteria: focus and level of intervention. The former can be characterized by the types of persons who utilize the service and the dimension it is concerned with (study, work, career). Three categories can thus be defined:

1. educational guidance or services to assist the students in their educational and professional endeavors;

2. vocational guidance or services to assist the students in their educational and professional choices;

3. personal guidance or counselling services providing personal or relationship counselling services. If services are considered, instead, from the point of view of the level of intervention, three models can be defined:

1. services that are part of a formal didactic function,

2. services linked to a formal didactic function but requiring a specialization degree,

3. services that are unconnected to a formal didactic function and supported by specialists [2].

The tutoring and mentoring services promoted and actuated by the support service offered to the students enrolled in the Universities of Padua and Burgos belong to this last category. As student support does not focus entirely on didactic programs but is also concerned with educational problems and difficulties a student may experience while pursuing academic activities, it is particularly important that an efficacious link with university services deeply integrated in the university system is available particularly at the beginning of the university journey. The university and, in particular, teachers are compelled to compare traditional and advanced teaching methods and modalities of transmitting knowledge: tutoring and mentoring can play an important role in this process [3].

\section{Tutoring and mentoring}

Peer tutoring and mentoring in the Italian and Spanish university systems present different characteristics.

Mentoring and tutoring models generally aim to assist the newly enrolled student to achieve success in the academic and social dimensions.

There are, nevertheless, differences in these practices from social/communication as well as educational points of view. The term tutoring refers to the practice by which an expert (tutor) assists a novice in the learning process. As demonstrated by recent studies carried out in the academic ambience [4] [5] [6], the tutor's work in assisting in the transmission of knowledge, experience and expertise is enhanced and becomes more natural if the relationship between the student and the tutor is "au pair" (on an equal standing). The relationship becomes more efficacious because the two actors have a similar age and background.

Peer education, in fact, which means literally, education between peers, was utilized primarily in the Anglo-saxon schooling system as a means to prevent adolescents from abandoning the school. The 
peer tutoring process arose from the "educational practice by which, at the teacher's direction, more competent students assist those less competent in an cooperative effort on a one to one basis or in small groups" [7]. Tutoring has a double function: on the one hand, a social action is carried out to teach specific abilities linked to a particular context; on the other, it is a formative experience in terms of sharing and participatory learning.

Mentoring arose in the United States in the 1880 's in the attempt to prevent further diffusion of the phenomenon of scholastic abandonment and only later did it become widespread in the adult population and in subjects suffering from educational, social and professional distress [8].

Mentoring defines a one-on-one relationship between two parties: the mentor and the mentee. This type of process is particularly adapt within a job or educational context and is also used in social prevention programs. A predefined mentoring program does not exist as support in itself arises out of relationship which is founded and based on a voluntary choice made by both subjects.

Mentoring is, therefore a situation based on support and trust in which assistance is offered to one or more students who are experiencing a difficult period of transition. The process is based on a relationship in which the mentor aims to assist the mentee by preventing and overcoming social impairment, by empowering and helping to promote self-confidence and esteem as well as trust in others and thus promoting the student's general wellbeing

With respect to the tutor, the mentor is less bound to any institution and more focused on the relationship and the needs of the mentee.

In fact, that which distinguishes the mentor from the tutor is that the former is more oriented "towards providing emotional-affective support tending to enhance both identification with and distance from the self" and the relationship that develops between the two tends to be more empathic and participatory, while the tutor-student relationship is more functional and goal-oriented [9].

Table 1. A comparison of mentoring and tutoring models outlined in the literature (Isfol, 2005) [10]

\begin{tabular}{|c|c|c|}
\hline Type & Mentoring & Tutoring \\
\hline Aim/ target & $\begin{array}{l}\text { - Gives the } \\
\text { mentee a benign } \\
\text { form of support } \\
\text { depending on } \\
\text { his/her needs } \\
\text { - Does not } \\
\text { follow a } \\
\text { performance } \\
\text { logic (the aim is } \\
\text { not } \\
\text { performance) }\end{array}$ & $\begin{array}{l}\text { - Gives a } \\
\text { measured } \\
\text { support to the } \\
\text { student } \\
\text { depending on } \\
\text { the sponsor's } \\
\text { aims } \\
\text { - Follows a } \\
\text { performance } \\
\text { logic to } \\
\text { transmit know- } \\
\text { how, to improve } \\
\text { study habits, to } \\
\text { achieve better }\end{array}$ \\
\hline
\end{tabular}

\begin{tabular}{|c|c|c|}
\hline & & grades) \\
\hline $\begin{array}{l}\text { Applicatio } \\
\mathrm{n} \text { methods }\end{array}$ & $\begin{array}{l}\text {-The mentee } \\
\text { generally has } \\
\text { some say about } \\
\text { the choice of } \\
\text { the mentor } \\
\text {-The } \\
\text { relationship } \\
\text { between the } \\
\text { mentor and the } \\
\text { mentee is not } \\
\text { hierarchical } \\
\text {-It is a } \\
\text { relationship } \\
\text { based on trust } \\
\text { (No training } \\
\text { activities } \\
\text { involved) } \\
\text {-The mentor } \\
\text { aims to help the } \\
\text { mentee achieve } \\
\text { autonomy }\end{array}$ & $\begin{array}{l}\text {-The } \\
\text { institution/Orga } \\
\text { nization/Corpor } \\
\text { ation chooses } \\
\text { the Tutor } \\
\text {-There is a } \\
\text { hierarchical } \\
\text { relationship } \\
\text { between the } \\
\text { Tutor and the } \\
\text { Student } \\
\text {-It is a } \\
\text { relationship } \\
\text { based on trust } \\
\text { (the student will } \\
\text { continue to be } \\
\text { assisted until } \\
\text { he/she reached a } \\
\text { particular level } \\
\text { of expertise or } \\
\text { qualification) } \\
\text {-The student } \\
\text { may be assigned } \\
\text { activities or } \\
\text { excercises }\end{array}$ \\
\hline $\begin{array}{l}\text { Relations } \\
\text { between } \\
\text { protagonist } \\
\mathrm{s}\end{array}$ & $\begin{array}{l}\text {-One-to-one } \\
\text { relationship betw } \\
\text { the mentor and } \\
\text { mentee }\end{array}$ & $\begin{array}{l}\text { - There may } \\
\text { be a one-to-one } \\
\text { student } \\
\text { relationship or a } \\
\text { tutor may be } \\
\text { assigned to } \\
\text { small groups of } \\
\text { students }\end{array}$ \\
\hline Time spent & $\begin{array}{l}-2 \text { or } 3 \text { hours } \\
\text { per week }\end{array}$ & $\begin{array}{l}\text {-Several } \\
\text { hours per week } \\
\text { or month } \\
\text { characterized by } \\
\text { a commitment } \\
\text { over a long } \\
\text { period of time }\end{array}$ \\
\hline $\begin{array}{l}\text { Operators' } \\
\text { profile }\end{array}$ & $\begin{array}{l}\text {-Volunteers } \\
\text { receive no } \\
\text { compensation } \\
\text { or only to cover } \\
\text { expenses or } \\
\text { they may be } \\
\text { given credits (if } \\
\text { students) } \\
\text {-The person } \\
\text { doing the } \\
\text { mentoring may } \\
\text { be paid in the } \\
\text { case it is an } \\
\text { organization/ass } \\
\text { ociation that is } \\
\text { commissioning } \\
\text { the endeavor } \\
\text {-The } \\
\text { selection } \\
\text { process is } \\
\text { careful and } \\
\text { professionals }\end{array}$ & $\begin{array}{l}\text { - } \\
\text { Professionals } \\
\text { paid by schools, } \\
\text { corporations or } \\
\text { enterprises to } \\
\text { function, in } \\
\text { addition to their } \\
\text { own job, as } \\
\text { tutor or } \\
\text { externally paid } \\
\text { professionals } \\
\text {-The tutor } \\
\text { may be a paid } \\
\text { professional } \\
\text { who is not the } \\
\text { teaching staff, in } \\
\text { the case of peer- } \\
\text { tutors, students } \\
\text { carry out the } \\
\text { role } \\
\text {-The } \\
\text { selection }\end{array}$ \\
\hline
\end{tabular}




\begin{tabular}{|l|l|lr|}
\hline & $\begin{array}{l}\text { are usually } \\
\text { excluded } \\
\text {-Little } \\
\text { training/lot of } \\
\text { experience }\end{array}$ & $\begin{array}{l}\text { process is not } \\
\text { careful } \\
\text {-Little } \\
\text { training } \\
\text { necessary }\end{array}$ & is \\
\hline
\end{tabular}

\section{The University of Padua Tutoring Services}

Beginning in the 2001-2002 academic year, the University of Padua initiated tutoring services for freshmen students geared to give personalized attention to individual needs.

The tutoring service coordinates and manages all of the University of Padua's Junior Tutor activities. The University Tutor was inaugurated in 1990 by Italian Law 341 intended to offer support measures and services to students, assisting and guiding them, removing any obstacles to a successful academic career, as they actively become integrated in the university educational experience. Over the past ten years, Italian Universities have been promoting "support actions for their students," both by improving the educational and formative courses being offered and by sustaining the personal evolutionary process of each student (CRUI, 2000) [11].

Adopting the well known Anglo-saxon peer tutoring model, the University of Padua has been implementing Tutorial Projects in all of its departments since 2001, (Lobato \& al., 2004) [12]. These projects have also been imported and adapted to other Italian and French universities (Pedicchio \& Fontana, 2003) [13].

\subsection{Purpose, Method, Addressee}

The tutoring services promoted by the University of Padua can be outlined in the following way:

-The Service's Purpose - the service's main functions are:

$\checkmark$ to provide advice, to furnish support, and to give information,

$\checkmark$ to teach and to reinforce effective study techniques,

$\checkmark$ to provide formative guidance.

-The Method Used - the means by which the services are carried out utilizes:

$\checkmark$ a check-in counter (open at specified consulting hours),

$\checkmark$ mail,

$\checkmark$ phone,

$\checkmark$ Skype,

$\checkmark$ formative guidance meetings,

$\checkmark$ study groups,

$\checkmark$ exercises,

$\checkmark$ support to the teach/didactic laboratories,

$\checkmark$ support to the teach/didactic register's offices and ex-Academic Deans.
-Addressees, the tutoring service offers its activities to the following persons:

$\checkmark$ regularly enrolled students,

$\checkmark$ regularly enrolled students who are behind in their studies,

$\checkmark$ freshmen,

$\checkmark$ worker students,

$\checkmark$ high school students,

$\checkmark$ students participating in the Erasmus program,

$\checkmark$ students who are auditing classes (not officially enrolled),

$\checkmark$ teaching staff,

$\checkmark$ others (parents, relatives).

The outline provides an overview of the activities involved in University of Padua's tutoring services although it does not specify how, when, where, when and why they are carried out.

\subsection{Who, How, Why}

In view of the tutoring services' aims, its activities fall under three major areas:

$\checkmark$ to support enrolled students by providing information about didactics and University life,

$\checkmark$ to assist students in preparing for particular difficult exams utilizing exercises and/or support provided by didactic laboratories,

$\checkmark$ to give support and guidance to the freshman student.

The person/s who may be interested in these activities can be categorized into three different typologies:

$\checkmark$ an individual,

$\checkmark$ a group,

$\checkmark$ other (the tutoring services also plans and organizes meetings open to the citizenry).

With regard to persons who might be interested in utilizing these services, four different at times combined types are usually found:

$\checkmark$ gender: both men/women,

$\checkmark$ age: young people who enrolled in the university immediately after high school and older individuals who return or approach university studies at a later date,

$\checkmark$ university status: enrolled/not enrolled, students on time with their exams/students behind in their studies ,

$\checkmark$ employment status: student/worker, student/student, worker. 
Table 2. Breakdown of the tutoring services offered by the University of Padua

\begin{tabular}{|c|c|c|c|}
\hline & $\begin{array}{l}\text { Informative } \\
\text { Tutoring }\end{array}$ & $\begin{array}{l}\text { Didactic } \\
\text { Tutoring }\end{array}$ & $\begin{array}{l}\text { Tutoring } \\
\text { Supporting } \\
\text { Other } \\
\text { Services }\end{array}$ \\
\hline$\sum_{i}^{\infty}$ & $\begin{array}{l}\text { Furnishes } \\
\text { consultation } \\
\text { services, } \\
\text { provides } \\
\text { support and } \\
\text { gives } \\
\text { information }\end{array}$ & $\begin{array}{l}\text { Provides } \\
\text { didactic } \\
\text { support }\end{array}$ & $\begin{array}{l}\text { Provides } \\
\text { counselling } \\
\text { about } \\
\text { possible } \\
\text { study } \\
\text { choices }\end{array}$ \\
\hline \multicolumn{4}{|c|}{$\begin{array}{l}\text { Method: } \\
\text { e individual or a group } \\
\text { of students }\end{array}$} \\
\hline
\end{tabular}

Types of persons requiring tutoring services:

Persons (kind): Both Male-Female

Age: Young persons (who enroll in the

University immediately after high school), older persons (who begin or return to university studies later in life)

University status: Enrolled/not enrolled, on time with exams/behind schedule on exams

Occupational status: Student,

Student worker, Worker student

\begin{tabular}{|c|c|c|}
\hline $\begin{array}{l}\text { General } \\
\text { information } \\
\text { about } \\
\text { (class rooms, } \\
\text { services, } \\
\text { teachers, fees, } \\
\text { uniweb,..) } \\
\text { Didactic } \\
\text { information } \\
\text { (plan of } \\
\text { studies, } \\
\text { information } \\
\text { about and } \\
\text { choice of } \\
\text { exams, } \\
\text { eligibility) } \\
\text { Information } \\
\text { about } \\
\text { administrative } \\
\text { procedures } \\
\text { and } \\
\text { paperwork } \\
\text { (transferring, } \\
\text { applying for } \\
\text { recognition of } \\
\text { student status, } \\
\text { enrolling, } \\
\text { signing up for } \\
\text { classes) }\end{array}$ & $\begin{array}{l}\begin{array}{l}\text { Study and } \\
\text { exercise } \\
\text { groups }\end{array} \\
\text { Organizing } \\
\text { didactic } \\
\text { laboratorie } \\
\text { s }\end{array}$ & $\begin{array}{l}\text { Informative } \\
\text { counselling } \\
\text { (information } \\
\text { is provided } \\
\text { concerning } \\
\text { classes, } \\
\text { courses, } \\
\text { courses of } \\
\text { study, } \\
\text { services and } \\
\text { assistance } \\
\text { being offered } \\
\text { enrolled } \\
\text { students) } \\
\text { Counselling } \\
\text { and helping } \\
\text { students with } \\
\text { apprenticeshi } \\
\text { ps and/ or } \\
\text { preparing } \\
\text { dissertations } \\
\text { Participating } \\
\text { in events } \\
\text { promoted by } \\
\text { the service } \\
\text { Consultation } \\
\text { with other }\end{array}$ \\
\hline
\end{tabular}

\begin{tabular}{|l|l|l|}
\hline & $\begin{array}{l}\text { services that } \\
\text { the } \\
\text { department or } \\
\text { University } \\
\text { offers (for } \\
\text { instance, the } \\
\text { Psychological } \\
\text { Service) }\end{array}$ \\
& $\begin{array}{l}\text { Monitoring } \\
\text { student } \\
\text { progress }\end{array}$ \\
\hline
\end{tabular}

\subsection{University of Padua's Tutoring Activities}

The University of Padua's Tutoring services offer, as we have seen, a support tool for students and the tutoring activities fall into two categories, depending on the sector that organizes them:

$-\mathrm{C} / \mathrm{O}$ (care of) didactic organization,

$-\mathrm{C} / \mathrm{O}$ (care of) the central tutorial service office.

\subsection{Tutoring $\mathrm{C} / \mathrm{O}$ didactic organizations}

Tutoring activities $\mathrm{C} / \mathrm{O}$ didactic organizations fall into three categories:

-informative tutoring (front office) the tutor is seen as mediator between the university system and the student. The tutor helps to integrate first-year students, offers various kinds of information (regarding courses of study, exams, preparation of thesis/dissertation, administrative procedures), as well as advice and support. The tutor will, moreover, facilitate student-teacher communication and act as the student's link to the university system in general,

-study tutoring (study groups) helps to teach students study techniques especially in view of preparing for particularly difficult exams or thesis/dissertation preparation,

-tutoring to support university's services support and guidance activities realized for the students needs [14].

Informative tutoring: furnishes consultation services and support and provides information

- General information,

- Didactic information,

- Information on administrative requirements.

Table 3. Activities and Services of Informative Tutoring

\begin{tabular}{|l|l|}
\hline $\begin{array}{l}\text { Services } \\
\text { and/or } \\
\text { activities }\end{array}$ & $\begin{array}{l}\text { Brief description of services } \\
\text { and/or activities offered }\end{array}$ \\
\hline $\begin{array}{l}\text { General } \\
\text { Information }\end{array}$ & $\begin{array}{l}\text { The student calls or contacts the } \\
\text { junior tutor by e-mail or Skype } \\
\text { during working hours to receive } \\
\text { information of a general } \\
\text { character about his/her course of } \\
\text { studies, where classes are } \\
\text { located, existing services, } \\
\text { teachers, fees, tuition, uniweb, }\end{array}$ \\
\hline
\end{tabular}




\begin{tabular}{|l|l|}
\hline & etc. \\
\hline Didactic & $\begin{array}{l}\text { The student calls or contacts the } \\
\text { junior tutor by e-mail or Skype } \\
\text { during working hours to receive } \\
\text { specific information concerning } \\
\text { didactics, such as how to } \\
\text { organize one's course of studies, } \\
\text { the choice of exams especially } \\
\text { with regard to optional ones, } \\
\text { eligibility, etc. }\end{array}$ \\
\hline $\begin{array}{l}\text { Information } \\
\text { about } \\
\text { administrative } \\
\text { requirements/ } / \text { paperwent calls or contacts the } \\
\text { paperwork }\end{array}$ & $\begin{array}{l}\text { junior tutor by e-mail or Skype } \\
\text { during working hours to receive } \\
\text { specific information concerning } \\
\text { forms and paperwork needed for } \\
\text { transferring from other } \\
\text { universities, credit recognition, } \\
\text { recuperating university credits, } \\
\text { re-enrollment and enrollment } \\
\text { procedures, etc. }\end{array}$ \\
\hline
\end{tabular}

Study tutoring: Teaching study methods

-Organizing and holding didactic laboratories,

-Group studies, some including exercises or laboratories.

Table 4. Activities and Services of Didactic Tutoring

\begin{tabular}{|l|l|}
\hline $\begin{array}{l}\text { Services } \\
\text { and/or } \\
\text { activities }\end{array}$ & $\begin{array}{l}\text { Brief description of services and/or } \\
\text { activities offered }\end{array}$ \\
\hline $\begin{array}{l}\text { Support } \\
\text { during } \\
\text { didactic } \\
\text { laboratories }\end{array}$ & $\begin{array}{l}\text { The student is assisted during } \\
\text { didactic laboratories that are a part } \\
\text { of a course requirement. The tutor } \\
\text { assists the teacher aiding him/her in } \\
\text { communicating with the students } \\
\text { and in the learning process during } \\
\text { didactic laboratory activities. }\end{array}$ \\
\hline $\begin{array}{l}\text { Group } \\
\text { studies and }\end{array}$ & $\begin{array}{l}\text { The student is instructed about } \\
\text { efficacious study techniques } \\
\text { especially with regard to particularly } \\
\text { difficult subjects. A closer, deeper } \\
\text { look is taken to subjects that the } \\
\text { Professor mentioned only briefly in } \\
\text { class but may not be clear to the } \\
\text { students. This is done to create an } \\
\text { interactive climate by encouraging } \\
\text { the student's interest in the subject } \\
\text { and participation in class. }\end{array}$ \\
\hline
\end{tabular}

\section{Tutoring supporting university's services:}

- Informative counselling (with regard to the didactic courses, services and activities available to the student),

- Support/counselling available to apprentices or in preparation of graduation/thesis,

- Participation in events organized by the service,

- Consultation with other University services for example the Psychological Service,

- Monitoring student progress.
Table 5. Tutoring Activities and services linked to other services

\begin{tabular}{|c|c|}
\hline $\begin{array}{l}\text { Services } \\
\text { and/or } \\
\text { activities }\end{array}$ & $\begin{array}{l}\text { Brief description of services } \\
\text { and/or activities offered }\end{array}$ \\
\hline $\begin{array}{l}\text { Informative } \\
\text { counselling }\end{array}$ & $\begin{array}{l}\text { The student contacts the Junior } \\
\text { Tutor in person, by phone, or by } \\
\text { Skype during office hours to } \\
\text { receive specific information about } \\
\text { didactic courses being offered by } \\
\text { that specific Faculty. } \\
\text { The Junior Tutor counsels the } \\
\text { student about courses of studies, } \\
\text { services offered by the Faculty, } \\
\text { past and future initiatives, job } \\
\text { opportunities. }\end{array}$ \\
\hline $\begin{array}{l}\text { Support/coun } \\
\text { selling } \\
\text { available to } \\
\text { apprentices or } \\
\text { in preparation } \\
\text { of graduation/ } \\
\text { thesis }\end{array}$ & $\begin{array}{l}\text { The student contacts the Junior } \\
\text { Tutor in person, by phone, or by } \\
\text { Skype during office hours to } \\
\text { receive specific information and } \\
\text { advice about apprenticeships that } \\
\text { may be available or with regard to } \\
\text { details connected to thesis } \\
\text { preparation. } \\
\text { With regard to the former, the } \\
\text { Junior Tutor assists the student in } \\
\text { the process of identifying which } \\
\text { department/faculty is offering } \\
\text { positions and how/where to apply. } \\
\text { With regard to the latter, the Junior } \\
\text { Tutor outlines the various } \\
\text { steps/phases required for } \\
\text { graduation and those connected to } \\
\text { choosing the subject of the thesis } \\
\text { and Professor/assistant professor } \\
\text { who will act as the thesis advisor. }\end{array}$ \\
\hline $\begin{array}{l}\text { Participation } \\
\text { in events } \\
\text { organized by } \\
\text { the service }\end{array}$ & $\begin{array}{l}\text { The students participates in the } \\
\text { various activities organized by the } \\
\text { Tutor Junior linked to informative } \\
\text { counselling such as Open Day and } \\
\text { meetings during which didactic } \\
\text { courses being offered by the } \\
\text { departments are outlined. }\end{array}$ \\
\hline $\begin{array}{l}\text { Consultation } \\
\text { with other } \\
\text { departments } \\
\text { or services of } \\
\text { the University }\end{array}$ & $\begin{array}{l}\text { The students calls or contacts the } \\
\text { Junior Tutor in person, by phone, } \\
\text { e-mail or Skype during working } \\
\text { hours. The Junior Tutor counsels } \\
\text { the student regarding the } \\
\text { problems/necessities that are } \\
\text { expressed and recommends other } \\
\text { service provided by the University } \\
\text { (e.g. the Psychological service,...) }\end{array}$ \\
\hline $\begin{array}{l}\text { Monitor } \\
\text { student } \\
\text { progress }\end{array}$ & $\begin{array}{l}\text { The Junor Tutor monitors the } \\
\text { student's progress by gathering } \\
\text { data ad hoc and analyzing the } \\
\text { types of student who might be } \\
\text { interested in utilizing the service. } \\
\text { Data is collected, computerized } \\
\text { and analyzed. }\end{array}$ \\
\hline
\end{tabular}




\subsection{Tutoring C/O Central Tutorial Office}

The tutoring activities managed by the central tutorial service office intend to promote collaboration with other services available to the enrolled students.

Recent research [15] has demonstrated that students use the services offered by the University system often and efficiently when those are organized in relation to students' real needs/requirements. Experimental projects underway at the central Tutorial service are:

$\checkmark$ dropout tutoring and support (this sector studies the causes putting students at risk of failure and offers special assistance),

$\checkmark$ prison tutoring (organizes support activities for inmates of the male prison located in Padua),

$\checkmark$ orientation tutoring and support (the front office offers students guidance and support),

$\checkmark$ tutoring service for disabled students (disable students receive assistance personalized to their particular needs),

$\checkmark$ The Regional Right to University Study Office (ESU ) tutoring and support for students in danger of dropping out ( the ESU office works together with the University residence offices to assist students residing in dormitories,

$\checkmark$ Psychological Assistance Service (SAP) counselling and tutoring for students requiring psychological assistance Beginning with the next academic year two new experimental projects will be inaugurated:

$\checkmark$ Mentor-UP tutoring and support (children and preteens at risk will be able to benefit from Junior Tutors),

$\checkmark$ Buddy tutoring and support (foreign and exchange students enrolled at University of Padua will be able to benefit from the tutoring system).

\section{The Mentor Program at the University of Burgos (UBU)}

The Spanish mentoring experience was initiated few years ago. The promoters of the S.I.M.U.S Project (Valverde Macías, et al. 2003) [16] at the University of Seville (García Jiménez et al., 2004) [17] reported that mentoring is a critical resource as it sets into motion an innovative process aiming to assist and to guide newly enrolled students. This is done to enhance the student's overall development; but the project also intends to provide benefits for both the mentee and mentor as well as for the institution itself by improving relationships and communication between the students and the teaching staff. The institution will thus become more deeply involved in helping students to learn more efficaciously. The students will be helped to meet the new demands at the university and - through collaborative efforts - will progress successfully in the academic environment.

A number of universities recently joined together in the Spanish University Mentoring Environments
Network [18] which aims to unite their efforts, sharing/comparing experiences to find similarities in order to analyze and develop rigorous mentoring programs [19].

These analyses and efforts led to the initiation of peer counseling at our University at the 2009/10 academic year. The program's general objectives are: $\checkmark$ to provide new students at the University of Burgos the assistance and guidance they need to be successful in their studies and to facilitate their academic and social integration in the institution.

Its specific objectives are:

$\checkmark$ to assist the student in his/her academic development and to provide seeds of reflection with regard to the academic environment, helping the student to become critical and autonomous,

$\checkmark$ to promote the development of a respectful, responsible attitude towards other students and the institution,

$\checkmark$ to facilitate the transition of freshman students,

$\checkmark$ to encourage students to fully participate in university life and to be aware of all of the services that are available,

$\checkmark$ to support students emotionally in overcoming academic difficulties or problems with keeping apace,

$\checkmark$ to provide keys for future professional performance,

$\checkmark$ to act as a guide for lifelong learning,

$\checkmark$ to reduce the dropout rate and to increase the number of the new students,

$\checkmark$ to improve the university's quality.

\subsection{Participants: descriptions and internal organization}

Participants in the program are teacher-tutors, student-mentors, student-mentees, the mentorcoordinator and the tutor coordinators. Each teachertutor is assigned a maximum of three students and each student-mentor a maximum of five mentees. These are the profiles and functions of each:

a. The teacher-tutor is a university professor who assists and monitors the student-mentor and the student-mentee. He/she schedules meetings (setting up locations and times) with mentors and mentees. $\mathrm{He} / \mathrm{she}$ evaluates and how each is progressing. $\mathrm{He} / \mathrm{she}$ is involved in the coordination and diffusion of the project and in getting other teachers interested in participating;

b. The student-mentor is a second-level student who will be assigned a maximum five mentees enrolled in the same course of studies. He/she is available to give advice and guidance based on his/her own experience and knowledge. He/she encourages the student to participate actively, to attend meetings, and he/she prepares a final report;

c. The student-mentee is a first-level student who requests guidance with reference to his/her studies at the university and the services that are available. Assistance may be required with regard to decisions 
concerning courses of studies, courses, credits, grants, accommodation, services, tutoring, exams, library, cultural and sports activities, administrative and bureaucratic matters. The student attends meetings, participates in interviews, develops social and professional skills, participates in some phases of project analysis;

d. The Mentor-Coordinator is a member of the Faculty who is in charge of the student-mentors. $\mathrm{He} / \mathrm{she}$ convokes meetings with mentors, encourages student participation by setting information campaigns into motion, he/she reports to the Teacher Training Department and the Vice-rector with regard to progress and prepares a final report;

e. The Project Management Director is the director of the Permanent Education Department and may also be the teacher-tutor coordinator director. She/he is responsible for their training and all decisions related to the project. He/she convokes meetings, reports to and updates the Vice-rector; encourages other teachers to participate and prepares the final report. Together with the mentoring coordinator, he/she selects potential mentors, assigns new students to the mentor and evaluates the performance of the mentors and the tutors.

A variety of meetings are scheduled regularly:

-The student-mentor with the student-mentee: interviews are held.

-The mentor-student with the Teacher-tutor: meetings are held monthly to discuss problems, solutions, and future activities,

-The mentor-Student with the mentorcoordinator: meetings are held monthly to discuss problems, solutions, and future activities as well as to evaluate the project's development and progression

-The teacher-tutors and the Mentor Coordinator: Meetings are held monthly to analyze new initiatives and to introduce modifications whenever necessary.

\subsection{The functions of the members participating in this Program}

The role of the three main figures is more fully outlined below.

\subsection{The Student-mentor}

The mentor-student establishes a relationship with new students and in view of his/her own experience helps to solve different problems/situations and to facilitate their transition into the university community.

The main functions of the student-mentors are the following:

$\checkmark$ to promote the Mentor Program in all their contacts with new first-level students enrolled in his/her own course of studies,

$\checkmark$ to encourage colleagues/fellow students to become mentors (there are some courses of studies in which there are no mentors), $\checkmark$ to participate in initiatives to coordinate and develop the program,

$\checkmark$ to advise, inform and guide the student-mentee on topics concerning:

-Academics: curriculum, course selection, credits, virtual campuses, libraries, and study habits, etc.,

-Administrative: academic standards, grants and scholarships matriculation procedures, mobility and exchange programs,

-Social organization, structure, functioning and UBU services, lodging, transportation, dining halls, etc.,

$\checkmark$ to help new students in the transition to University life,

$\checkmark$ to convoke meetings (timing, location and hours) to discuss mentoring,

$\checkmark$ to attend four obligatory meetings convoked by the tutor (every 45 days approximately). The meetings will review the tasks and/or activities and resolve doubts and difficulties,

$\checkmark$ to attend two obligatory meetings convoked by the coordinator.

\subsection{The Student-mentee}

Freshman students are required to participate in all of the activities that are proposed by the mentor and to maintain a respectful participatory attitude towards learning and the opportunities offered by the University.

\subsection{Teacher-tutor}

The figure of the teacher-tutor can be considered a link between the student-mentors and the program management as well as a point of reference for students.

The main functions of the Teacher-tutor are the following:

$\checkmark$ to encourage fellow teachers to participate in the program,

$\checkmark$ to promote the Mentor Program among new students,

$\checkmark$ to participate in developing and coordinating the project,

$\checkmark$ to advise, inform and guide the student-mentor with regard to:

-Academic matters: curricula, credits, courses, conferences, study habits, etc...

-Institutional matters: organization, structure, function and services at the UBU.

- Organization and group management matters: leadership, problem solving and conflict resolution, motivation...

$\checkmark$ to assist mentors in their contacts with mentees,

$\checkmark$ to convoke meetings (timing, location and hours) with their student-mentors: at least 4 meetings during each academic term, 
$\checkmark$ to develop a calendar for the activities carried out by the mentors activities,

$\checkmark$ to collaborate in coordinating the teaching staff; to provide the teachers with ideas and suggestions,

$\checkmark$ to participate in various activities outlined in the UBU Web page, workshops, excursions etc.,

$\checkmark$ to be available to the student-mentors at meetings and to analyze project results.

$\checkmark$ to assess the work of the student-mentors.

$\checkmark$ to draft a final report evaluating the Project.

Teachers should not focus exclusively on the mentors; they can maintain a direct and/or indirect link with the mentees, as the program aims to create a link between all its components.

\section{Comparison between the tutoring and mentoring models of the University of Padua and the University of Burgos}

As outlined in Table 6, the tutoring/mentoring programs of the two universities analyzed here have been delineated in the following way:

$\checkmark$ project name,

$\checkmark$ mentor/tutor name,

$\checkmark$ start of mentor/tutor's program,

$\checkmark$ objective of the program,

$\checkmark$ duration of the program

$\checkmark$ number of students mentor/tutor to Faculty

$\checkmark$ requirements to become a student mentor/tutor

$\checkmark$ how the mentor/tutor is reimbursed

$\checkmark$ students mentor/tutor activities,

$\checkmark$ how many students/mentee each mentor/tutor can be assigned

$\checkmark$ students mentor/tutor selection,

$\checkmark$ students mentor/tutor training.

Table 6. Comparison between the tutoring and mentoring models at the University of Padua and the University of Burgos

\begin{tabular}{|l|l|l|}
\hline \multicolumn{1}{|c|}{ Item } & University of Padua & $\begin{array}{l}\text { University of } \\
\text { Burgos }\end{array}$ \\
\hline $\begin{array}{l}\text { Project } \\
\text { name }\end{array}$ & $\begin{array}{l}\text { TUTORIAL } \\
\text { SERVICE }\end{array}$ & $\begin{array}{l}\text { MENTOR } \\
\text { PROJECT }\end{array}$ \\
\hline Title used & Junior Tutor & $\begin{array}{l}\text { Mentor } \\
\text { Student }\end{array}$ \\
\hline $\begin{array}{l}\text { The } \\
\text { mentor/tut } \\
\text { or } \\
\text { program } \\
\text { began in }\end{array}$ & in 2001 & in 2009 \\
\hline $\begin{array}{l}\text { Objective } \\
\text { of the } \\
\text { service/pr } \\
\text { oject }\end{array}$ & $\begin{array}{l}\text { to } \\
\text { integration facilitate } \\
\text { freshman students } \\
\text { and to assist those } \\
\text { with }\end{array}$ & $\begin{array}{l}\text { to facilitate } \\
\text { integration of } \\
\text { freshman } \\
\text { students }\end{array}$ \\
\hline
\end{tabular}

\begin{tabular}{|c|c|c|}
\hline & difficulties & \\
\hline $\begin{array}{l}\text { Duration } \\
\text { of the } \\
\text { program }\end{array}$ & $\begin{array}{l}\text { throughout their stay } \\
\text { at the University }\end{array}$ & $\begin{array}{l}\text { only during } \\
\text { the first year, } \\
\text { from } \\
\text { September to } \\
\text { March }\end{array}$ \\
\hline $\begin{array}{l}\text { The } \\
\text { tutor/ment } \\
\text { or faculty } \\
\text { ratio }\end{array}$ & $\begin{array}{l}\text { each Faculty has a } \\
\text { different } \\
\text { faculty ratio }(2-30)\end{array}$ & $\begin{array}{l}\text { each Faculty } \\
\text { has } \\
\text { different } \\
\text { mentor- } \\
\text { faculty ratio }\end{array}$ \\
\hline $\begin{array}{l}\text { Who can } \\
\text { become } \\
\text { mentor/tut } \\
\text { ors }\end{array}$ & $\begin{array}{l}\text { the tutor are pre- or } \\
\text { post -doc students }\end{array}$ & $\begin{array}{l}\text { the mentors } \\
\text { are students } \\
\text { enrolled in } \\
\text { higher } \\
\text { courses }\end{array}$ \\
\hline $\begin{array}{l}\text { Reimburs } \\
\text { ement of } \\
\text { mentor/ } \\
\text { tutors }\end{array}$ & $\begin{array}{l}\text { tutors are paid bi- } \\
\text { monthly } \\
\text { (approximately } 16 \\
\text { euro an hour) }\end{array}$ & $\begin{array}{l}\text { mentors earn } \\
1,5 \text { credits of } \\
\text { optional } \\
\text { courses and } \\
\text { free cards to } \\
\text { sporting } \\
\text { events }\end{array}$ \\
\hline $\begin{array}{l}\text { Mentor/ } \\
\text { Tutors } \\
\text { activities }\end{array}$ & $\begin{array}{l}\text { the tutor offers } \\
\text { information and } \\
\text { resolves doubts } \\
\text { about: scholarships, } \\
\text { exams preparation, } \\
\text { communication with } \\
\text { academic } \\
\text { organizations and } \\
\text { offices. } \\
\text { The tutor manages } \\
\text { study groups } \\
\text { prepares private } \\
\text { lessons of exercises }\end{array}$ & $\begin{array}{l}\text { The mentor } \\
\text { offers } \\
\text { information } \\
\text { and resolves } \\
\text { doubts about } \\
\text { mentee } \\
\text { related to the } \\
\text { resources of } \\
\text { the university }\end{array}$ \\
\hline $\begin{array}{l}\text { How } \\
\text { many } \\
\text { students } \\
\text { does the } \\
\text { tutor/ } \\
\text { mentor } \\
\text { follow }\end{array}$ & $\begin{array}{l}\text { the number change } \\
\text { depending on the } \\
\text { Faculty and the kind } \\
\text { of activities } \\
\text { involved }\end{array}$ & $\begin{array}{l}\text { each mentor } \\
\text { may have a } \\
\text { maximum of } \\
5 \text { students }\end{array}$ \\
\hline $\begin{array}{l}\text { Students } \\
\text { mentor/ } \\
\text { tutor } \\
\text { selection }\end{array}$ & $\begin{array}{l}\text { Tutor are selected in } \\
\text { July once the } \\
\text { openings have been } \\
\text { publicized }\end{array}$ & $\begin{array}{l}\text { the deadline } \\
\text { to sign up as } \\
\text { a student } \\
\text { mentor is } \\
\text { open } \\
\text { throughout } \\
\text { the academic } \\
\text { years. } \\
\text { Candidates } \\
\text { must undergo } \\
\text { an interview }\end{array}$ \\
\hline $\begin{array}{l}\text { Students } \\
\text { mentor/ } \\
\text { tutor } \\
\text { training }\end{array}$ & $\begin{array}{l}\text { training lasts two } \\
\text { days in late August } \\
\text { or early September. } \\
\text { The tutors are } \\
\text { provide information }\end{array}$ & $\begin{array}{l}\text { each teacher } \\
\text { trains a } \\
\text { maximum of } \\
3 \text { mentors. } \\
\text { The training }\end{array}$ \\
\hline
\end{tabular}




\begin{tabular}{|l|l|lr|}
\hline about the university & course for \\
and faculty as well & mentors is \\
as the basic & held in July \\
cognitive and & and \\
motivational & September \\
principles of student & \\
tutorship. A student \\
cannot act as a tutor \\
for more for than \\
two academic years
\end{tabular}

\subsection{Questions and considerations for discussion}

Here are some questions aiming to promote reflection on various aspects of tutoring-mentoring activities at the university level:

$\checkmark$ Have the mentoring-tutoring services at the two universities outlined here helped to lower the rate of university failure and drop-outs?

$\checkmark$ Could these support systems be integrated in all universities to enhance/complement the teacher student relationship?

$\checkmark$ Is it feasible to create a non-voluntary automatic assignment of a student who is entering and one who is nearly at the end of the academic course of studies?

$\checkmark$ Some universities have created an academic mentoring/tutoring teaching system: in what way can a mentoring/tutoring system be considered university teaching?

\section{Acknowledgements}

This is a collaborative work on the part of all of the authors. More specifically, Da Re L. drafted sections 1-2-3 and their subsections; Casado-Muñoz R. and Collado-Fernández M. drafted section 4 and its subbsections. Section 5 was drafted in a collaborative effort. This is part of a University of Padua strategic project that aims to analyze and prevent student learning difficulties ("Learning difficulties and disabilities from primary school to university: diagnosis, intervention and services for the community" - STPD08HANE_005).

\section{References}

[1] A. Felice (edited by), "L'accompagnamento per contrastare la dispersione universitaria. Mentoring e tutoring a sostegno degli studenti", I libri del Fondo sociale europeo, Isfol, Rubbettino Industrie Grafiche ed Editoriali, Catanzaro, 2005, pp. 13-20.

[2] S.G Watts, R. Van Esbroeck, New skills for new futures. A synthesis report of a study on a new skills for vocational guidance in higher education, Fedora, Vub University Press, Bruxelles, 1998.

[3][12] F. Arbizu, C. Lobato and L. del Castillo, "Algunos modelos de abordaje de la tutoría universitaria", Revista de
Psicodidáctica, 10 (1), 2005, pp. 7-12.

[4] P. Álvarez, "La tutoría y la orientación universitaria en la nueva coyuntura de la enseñanza superior: El programa velero", Contextos educativos (8-9), 2005, pp. 281-293.

[5] J.F. González, E. Macías, R. Rodríguez, R. García, J.L. Aguilera, "Selección, formación y práctica de los docentes investigadores", La carrera docente, Madrid Universitas, 2009.

[6] U. Rodríguez, M.V. Pérez, M.B. Arenas Parra, A. Bilbao Terol, J. Antomil Ibias, "La Acción Tutorial en la Universidad en el Marco del Espacio Europeo de Educación Superior" Actas XV Jornadas de ASEPUMA, Mallorca, 2007.

[7] E. Torre, Il Tutor: teorie e pratiche educative, Carrocci, Roma, 2006, pp. 14-16.

[8] B.R. Gelli, T. Mannarini, Il mentoring. Uno strumento contro la dispersione scolastica, Carrocci, Roma, 1999.

[9] C. Biasin, L'accompagnamento, Teorie, pratiche, contesti, Franco Angeli, Milano, 2010, pp. 57-68.

[10] A. Felice (edited by), "Guida al mentoring istruzioni per l'uso", I libri del Fondo sociale europeo, Isfol, Rubbettino Industrie Grafiche ed Editoriali, Catanzaro, 2005, pp. 18-24.

[11] Crui, "Sul tutorato nelle università", contacted at the following link: www.crui.it, 2000, p. 3.

[13] M.C. Pedicchio and I. Fontana, (edd.), "Tutoring in European Universities", Commissione Europea, Trieste, 2003, pp. 7-10.

[14] L. Da Re and G. Zago, "Academic tutoring and dispersion: a project of research of the university of Padua (Italy)", in Atti del convegno ICERI 2011 (International Conference of Education, Research and Innovation) 14-16 Novembre 2011, Madrid, 2011, pp. 1457-1467.

[15] L. Fabbris, "Una ricerca sui servizi universitari innovativi per studenti e laureati", in L. Fabbris, G. Boccuzzo and M.C. Martini (edited by), Professionalità nei servizi innovativi per studenti universitari, Cleup, Padova, 2008, pp. 1-18.

[16] A. Valverde Macías, E. García Jiménez and S. Romero Rodríguez, "La función tutorial en la Universidad de Sevilla. La Mentoría como respuesta: El Proyecto SI.M.US. REDES de EDUCACIÓN", [4-02-09] www.redeseducacion.net/proyectosimus.htm.

[17] E. Garcia Jimenez, C. Ruis Miguel, S. Romero Rodriguez and A. Valverde Macias, "Innovación en la orientación universitaria: la mentoría como respuesta.", Contextos educativos, 6-7, 87-112.

[18] C. Sánchez Ávila, "Red de Mentoría en entornos universitarios: encuadre y objetivo", Ponencia III Jornadas Internacionales de Mentoring y Coaching, Universidad-Empresa, Madrid, 18-19 de Noviembre de 2008.

[19] P. Velasco, "Retos de la mentoría. Red de mentoría en entornos universitarios españoles", Ponencia III Jornadas 
International Journal for Cross-Disciplinary Subjects in Education (IJCDSE), Special Issue Volume 3 Issue 1, 2013

Internacionales de Mentoring y Coaching, Universidad-

Empresa, Madrid, 18-19 de Noviembre de 2008. 